\title{
POTENTIAL IMPACT OF INSECT HERBIVORES ON ORCHID CONSERVATION
}

\author{
MARILYN H. S. LIGHT and MICHAEL MACCONAILL \\ 174, rue Jolicoeur, Gatineau Québec Canada J8Z 1C9. E-mail: mlight@igs.net; Tel.: +1-819-776-2655; Fax: +1-819-776-3703
}

\begin{abstract}
When an orchid is deliberately or inadvertently relocated, it is likely to encounter a range of biological challenges to long term survival including a complex and dynamic insect community which could alter conservation expectations yet there have been few studies of the phytophagous insects associated with wild orchids. We have investigated the assemblage of such insects associated with terrestrial orchids being monitored in our long term studies in Gatineau Park, Québec, Canada. Aphids, leafminers, moths, thrips, weevils, and whiteflies were found to be injurious to orchids although in different combinations and with varying impact according to the orchid host, habitat and year. Loss of seeds and even complete desiccation of plants was observed. Where the leafminer, Parallelomma vittatum Meigen (Diptera: Scathophagidae) infested Cypripedium reginae Walter randomly, this was not the case with Cypripedium parviflorum var. pubescens (Willd.) Knight where specific plants were repeatedly infested. Some infestations such as with the leafminers seemed to be in equilibrium with parasitoids thus minimizing potential impact. A likely climate-related asynchrony of parasitoid and leafminer led to an outbreak in 2009 which heavily impacted the introduced Epipactis helleborine (L.) Crantz while a phenological shift in a thrips primary host, Trillium grandiflorum (Michaux) Salisb. (Melanthiaceae), in 2010, contributed to severe herbivory in habitats where both E. helleborine and trillium occurred. If climate change can lead to changes in insect abundance and impact on orchids, it would be useful to investigate the potential impact of phytophagous insects before assisted migration is considered as a conservation measure.
\end{abstract}

Keywords: Leafminer, asynchrony, Epipactis, Cypripedium, parasitoid, weevil

\section{Introduction}

Insects associate with plants in many ways including as herbivores where, according to Price (1980), more than one-half of animal herbivore species are insects which are detrimental to plants. Some feed and breed exclusively on one host but others may use a series of related or unrelated hosts to complete their life cycle. Whereas most emphasis in orchid-insect relationships has been placed upon insects as pollinators or as pests of naturalized or cultivated orchids, little has been published on native orchid-insect herbivore biology and ecology (Hawkeswood 1991a,b; Fiedler 1992; Hull Sieg and O’Brien 1993; Light and MacConaill 2002; Winkler et al. 2005; Dunford, et al. 2006; Ellis 2007; Funderburk et al. 2007). A review of the literature including phytosanitary interception reports (Swezey 1945), and taxonomic works where some biological information has been provided reveals a broad range of insects which feed and breed on orchids (Table 1). These insects likely have parasites including insects, mites, thrips and entomopathogens but little is known about these relationships except where a control agent has been sought to combat pests of cultivated plants (Bado et al. 2002; Loomans 2006; Vega et al. 2008; Hodek and Honĕk 2009).

Orchid ecosystems are complex assemblages of plants, animals and microorganisms not easily recognized over the short term. Weather can influence phenology and fruiting outcomes (Light and MacConaill 2002) but the ecosystem balance can also be altered by weather leading to insect pest outbreaks or population decline (Imle 1994; Light and MacConaill 2006; Sparks et al. 2006; Battisti 2008; Singer and Parmesan 2010; Yang and Rudolf 2010). Gough et al. (1994) noted that increases in temperature had a strong influence on pupal period of the dendrobium beetle, Stethopachys formosa Baly (Coleoptera: Chrysomelidae), when the pupation period decreased significantly from $72 \mathrm{~d}$ at $15.5^{\circ} \mathrm{C}$ to $15.5 \mathrm{~d}$ at $30.5^{\circ} \mathrm{C}$. This shift to shorter generation time could potentially enable this insect to complete more generations with climate warming. It is particularly challenging to predict insect population behaviour in a changing world when behaviour and regulation of many insect herbivores is not yet fully understood even under stable climatic conditions (Laštůvka 2009). Long term studies of orchid populations may detect sporadic swings in pest-host-parasite relationships but identifying and confirming the specific drivers of observed behaviour is difficult (Light and MacConaill 2005). Historic data obtained from the literature, herbaria and insect collections may provide useful clues to past behaviour and future trends but without an understanding of potential host-pest relationships before reintroduction or assisted migration is attempted, introduced orchids could encounter new pests or even reestablish a link between familiar pests or those which have invaded beforehand (Egan and Irwin 2008; Godefroid et al. 2011).

This investigation focused on the insect herbivores of three terrestrial orchids which are found in North Amer- 
Table 1 Insect herbivores of orchids.

\begin{tabular}{|c|c|c|c|c|c|c|}
\hline Order & Family & Genus & Species & Hosts & Origin: range & References \\
\hline \multirow{6}{*}{ Coleoptera } & \multirow[t]{2}{*}{ Chrysomelidae } & Stethopachys & formosa Baly & $\begin{array}{l}\text { Dendrobium Sw., } \\
\text { Cymbidium Sw. }\end{array}$ & $\begin{array}{l}\text { Australia, } \\
\text { introduced } \\
\text { elsewhere }\end{array}$ & Hawkeswood 1991a \\
\hline & & Stethopachys & papuana Gressitt & $\begin{array}{l}\text { Spathoglottis riviularis } \\
\text { Schlecht. }\end{array}$ & $\begin{array}{l}\text { Papua New } \\
\text { Guinea }\end{array}$ & Hawkeswood 1991b \\
\hline & Curculionidae & Orchidophilus & $\begin{array}{l}\text { atterimus } \\
\text { Waterhouse }\end{array}$ & Orchidaceae & Philippines & $\begin{array}{l}\text { Hara and Mau 1986, } \\
\text { Prena } 2008\end{array}$ \\
\hline & Curculionidae & Stethobaris & $\begin{array}{l}\text { commixta } \\
\text { Blatchley }\end{array}$ & Platanthera Rich. & $\begin{array}{l}\text { introduced } \\
\text { North America }\end{array}$ & $\begin{array}{l}\text { Hull Seig and O'Brien } \\
1993\end{array}$ \\
\hline & Curculionidae & Stethobaris & ovata LeConte & $\begin{array}{l}\text { Corallorhiza Gagnebin, } \\
\text { Cypripedium L., Epipactis } \\
\text { Zinn, Platanthera Rich. }\end{array}$ & North America & $\begin{array}{l}\text { Dunford, Young and } \\
\text { Krauth 2006, } \\
\text { Howden } 1995\end{array}$ \\
\hline & Dryophthoridae & Cactophagus & $\begin{array}{l}\text { graphipterus } \\
\text { Champion }\end{array}$ & Orchidaceae & $\begin{array}{l}\text { Central and } \\
\text { South America }\end{array}$ & Vaurie 1983 \\
\hline \multirow{2}{*}{ Diptera } & Cecidomyiidae & Contarinia & maculipennis Felt & Orchidaceae & Asia & Jensen 1946 \\
\hline & Scathophagidae & Parallelomma & vittatum Meigen & Orchidaceae & Holarctic & Vokeroth1987 \\
\hline \multirow{4}{*}{ Hemiptera } & Asterolecaniidae & $\begin{array}{l}\text { Aleurodiscus } \\
\text { Douglas }\end{array}$ & undescribed & $\begin{array}{l}\text { Maxillaria Ruiz } \\
\text { and Pavon }\end{array}$ & Costa Rica & Martin 2005 \\
\hline & Asterolecaniidae & Asterolecanium & epidendri Bouché & Orchidaceae & $\begin{array}{l}\text { Neotropics, } \\
\text { cultivated } \\
\text { orchids }\end{array}$ & Swezy 1945 \\
\hline & Asterolecaniidae & Cerataphis & $\begin{array}{l}\text { orchidearum } \\
\text { Westwood }\end{array}$ & Arecaceae, Orchidaceae & $\begin{array}{l}\text { Tropics, culti- } \\
\text { vated orchids }\end{array}$ & $\begin{array}{l}\text { Rivera-Coto and } \\
\text { Corrales-Moreira } 2007\end{array}$ \\
\hline & Miridae & Tenthecoris & bicolor J. Scott & Orchidaceae & South America & $\begin{array}{l}\text { Bado, Sills, Pannunzio } \\
\text { and Zapata 2002; } \\
\text { Rivera-Coto and } \\
\text { Corrales-Moreira } 2007\end{array}$ \\
\hline Hymenoptera & Eurytomidae & Eurytoma & $\begin{array}{l}\text { orchidearum } \\
\text { Westwood }\end{array}$ & Orchidaceae & South America & Doucette 1925 \\
\hline \multirow{2}{*}{ Lepidotera } & Tortricidae & Paralobesia & cypripediana Forbes & Cypripedium L. & North America & Heinrich 1926 \\
\hline & Lycaenidae & Hypolycaena & othona Hewitson & Orchidaceae & Asia & Fiedler 1992 \\
\hline \multirow{3}{*}{ Thysanoptera } & \multirow{3}{*}{ Thripidae } & Ctenothrips & bridwelli Franklin & Epipactis Zinn & North America & this paper \\
\hline & & Dichromothrips & corbetti Priesner & Orchidaceae & South Asia & Mound 2002 \\
\hline & & Pseudothrips & $\begin{array}{l}\text { beckhami Beshear } \\
\text { and Howell }\end{array}$ & $\begin{array}{l}\text { Calopogon R. Br., } \\
\text { Habenaria Willd. }\end{array}$ & North America & $\begin{array}{l}\text { Funderburk, Mound } \\
\text { and Sharma } 2007\end{array}$ \\
\hline
\end{tabular}

ica and have been the subject of study by the authors in Gatineau Park, Québec, Canada for more than two decades: Epipactis helleborine (L.) Crantz, Cypripedium parviflorum var. pubescens (Willd.) Knight, and Cypripedium reginae Walt.

Epipactis helleborine is an historic example of assisted migration but whether the movement was intentional is unclear. The orchid was first reported in North America from New York State in 1879 (Soper and Murray 1985), first recorded for Ontario, Canada in 1890 (W and O White, CAN 16431), and for Québec, Canada (1894, HB Cushing, CAN 16424) but the first discovery in Montréal, Québec was possibly by ND Keith in 1892 . Since the first report for North America, this orchid has spread widely (Soper and Murray 1985). The authors provide historic accounts of individuals transplanting E. helleborine to gardens including a comment by Szczawinski (1959) who suggested that those who had planted the orchid in gardens on southern Vancouver Island might regret it. Squirrel et al. (2001) determined that plants growing in Gatineau Park and elsewhere in eastern North America were of continental European origin. Since this orchid's first appearance in North America in the late 1800's, it has become widespread (Soper and Murray 1985) but it can be subject to population decline (Light and MacConaill 2006) and to herbivory. In 1985 , two completely dessicated plants of E. helleborine were noted where damage was attributed to an unidentified thrips (Light, unpublished). Herbivory by the orchidophilous weevil, Stethobaris ovata LeConte (Coleoptera: Curculionidae) has been reported where buds, stems and fruits are used for feeding and breeding (Champion 1916; Judd 1979; Howden 1995). Whether the assisted migration of E. helleborine was the deliberate movement of plants or an accidental importation of seeds, the introduction of this orchid and its subsequent exploitation by several insect herbivores 
presents an opportunity for detailed investigation toward an understanding some of the challenges to long term survival of an assisted migrant.

As a point of comparison with E. helleborine, two endemic Cypripedium species were selected for investigation of insect herbivory. Herbivory of the locally common and widespread C. parviflorum var. pubescens by $S$. ovata had been quantified by Light and MacConaill (2002) as part of a long term study in Gatineau Park where heavy damage was reported to fruits and seeds but only minor florivory and folivory was observed. Cypripedium reginae has been the subject of long term study in Gatineau Park since 2003. There are approximately 20 documented occurrences in Québec where the species is listed as Vulnerable (S3) (NatureServe). Loss of habitat, especially wetlands, herbivory, and poaching are recognized as being threats to $C$. reginae throughout its range, especially herbivory by deer (Odocoileus virginianus Zimmerman) (Gregg 2004) but less is known about the insects that use this orchid as a host. Occasional infestations of a leafminer have been observed with both C. parviflorum var. pubescens and C. reginae in Gatineau Park.

The objectives of this study were: 1) To quantify leafminer infestation in populations of C. parviflorum var. pubescens, C. reginae and E. helleborine; 2) To investigate and identify any parasites associated with the leafminer; 3) To investigate and identify the thrips associated with E. helleborine; and 4) To summarize the infestation of C. parviflorum and E. helleborine by the weevil, S. ova$\mathrm{ta}$; and 5) To investigate weather and climate change as a possible influence on insect herbivore behaviour and dynamics.

\section{Methods}

\section{Research sites and general approach}

This study was conducted in Gatineau Park, Québec, Canada, where orchid populations have been tracked for up to 26 years and where herbivore damage had been recorded as part of regular site visits.

\section{Epipactis helleborine}

The principal study area for E. helleborine was $135 \mathrm{sq} \mathrm{m}$ in a lightly forested mesic site (Site $1: 45^{\circ} 30^{\prime} \mathrm{N} ; 75^{\circ} 45^{\prime} \mathrm{W}$ ) where some 1800 plants have been individually tagged, mapped and tracked (1985-2010) (Light and MacConaill 2006). One plant of C. parviflorum var. pubescens and a few plants of Trillium grandiflorum (Michx.) Salisb. grow within this site. Several hundred additional E. helleborine growing within $500 \mathrm{~m}$ of the site were observed annually but only a few were tagged and tracked. Both flowering and vegetative plants were examined for the presence of herbivorous insects beginning in mid July, until hard frost $\left(-5{ }^{\circ} \mathrm{C}\right)$ in October/November or when deciduous trees dropped their leaves which covered the orchids.

\section{Cypripedium parviflorum var. pubescens}

A colony of approximately 400 flowering plants was located in a $250 \mathrm{sq} \mathrm{m}$ forested site $\left(45^{\circ} 30^{\prime} \mathrm{N} ; 75^{\circ} 45^{\prime} \mathrm{W}\right)$, approximately $1700 \mathrm{~m} \mathrm{SSE}$ of the E. helleborine study area. Data was collected for part of this population from 1996 to 1999 , and then from 2000 to 2009 when all the flowering plants were individually tagged, mapped, and tracked annually. In 2010, the colony was examined on three occasions for evidence of herbivory but only plants showing evidence of leaf mining were recorded by plant number. All plants were examined for the presence of insect herbivores on at least three occasions during a growing season, during flowering in May, during fruit development in June, and when mature fruits had developed in late $\mathrm{Au}$ gust. A large number ( $>200)$ of T. grandiflorum and small number $(<20)$ of E. helleborine were growing within and around the C. parviflorum colony: these plants were observed but not individually tagged or tracked.

\section{Cypripedium reginae}

A colony of approximately 300 flowering plants and seedlings located in a 10 ha wooded fen $\left(45^{\circ} 27^{\prime} \mathrm{N}\right.$; $\left.75^{\circ} 45^{\prime} \mathrm{W}\right)$, located approximately $1350 \mathrm{~m} \mathrm{~S}$ of the $E$. helleborine site and approximately $600 \mathrm{~m} \mathrm{NW}$ of the C. parviflorum site, was surveyed where plants were first individually tagged and mapped in 2003, and resurveyed in 2007 and 2008 (153, 260 and 133 plants respectively). To minimize disturbance of the orchid and habitat, only a subset of the population $(58,59,73,22$, and 55 plants) was assessed during 2004, 2005, 2006, 2009, and 2010, respectively. Surveys were conducted on at least three occasions annually over three months, June to August, from flowering until the plants senesced in mid to late August. A small number $(<40)$ of C. parviflorum and E. helleborine were found growing around the margin of the fen but not within the $C$. reginae colony: these plants were observed annually but not individually tagged or tracked.

\section{Weather data}

Data was obtained from the Canadian Climate Centre for the Ottawa Meteorological Station $\left(45^{\circ} 31^{\prime} \mathrm{N} ; 75^{\circ} 47^{\prime} \mathrm{W}\right.$, $100 \mathrm{~m}$ elevation), located approximately $18 \mathrm{~km}$ from the study areas.

\section{Insect herbivore survey}

Leaf mines were conspicuous and easily located for closer examination. The large white eggs of Parallelomma vittatum Meigen were laid in clutches firmly attached to the leaf undersurface where shells remained after hatching thus offering an opportunity for population studies (Vockeroth 1987). Tiny insects such as thrips were challenging to find without resorting to sweeping or similar methods which could be injurious to plants. Instead, plants were examined individually for signs of feeding damage which included speckling of the foliage. Suspect 
leaves were examined more closely for the presence of insects. Leaves were removed and examined using a microscope to see eggs. Capsule infestation by weevil larvae was determined by visual examination (Light and MacConaill 2002).

\section{Insect identification and vouchers}

Specimens were collected for identification purposes and to rear to maturity. Adult insects and associated parasites were submitted to the National Identification Service (Canada). Vouchers were deposited in the Canadian National Collection, Ottawa (CNC) and in the Lyman Entomological Museum, Montréal (LEMQ).

\section{Herbarium specimens examined for herbivory}

The National Herbarium of Canada, Canadian Museum of Nature (CAN), was visited to examine specimens of the three orchids. Signs of herbivore activity including leaf mines, eggs, feeding damage associated with fecal droplets characteristic of thrips, and exit holes in fruits were noted and photographed.

\section{Rearing leafminers and parasitoids}

Infested leaves containing last instar leafminer larvae were collected and held in ventilated containers to pupate when puparia were transferred to individual vials and held to eclosure of either leafminers or parasites. Any puparia not eclosed by October 1 were transferred to a refrigerator at $4{ }^{\circ} \mathrm{C}, 28 \% \mathrm{RH}$, for 5 months when samples were rewarmed to room temperature $\left(20^{\circ} \mathrm{C}\right)$ in subdued light at a $16 \mathrm{~h}$ photoperiod until eclosure. Infested foliage was also retained in closed containers at $20^{\circ} \mathrm{C}$ to see if any egg parasites emerged.

\section{Results}

\section{Weather}

Precipitation and temperature data are given in Table 2. Rainfall in July 2009 was exceptionally high with $243.4 \mathrm{~mm}$ recorded at Ottawa. The period from May to October 2009 was mainly cool and wet. Over the six month period, there were only 6 days with a daily maximum $>30{ }^{\circ} \mathrm{C}$ ( $2 \mathrm{~d}$ in late June; $4 \mathrm{~d}$ in mid Aug), in contrast to the long term median value of 12 days. There were 14 consecutive dry days in early September and 18 wet days during late September and early October.

\section{Insect herbivores and their parasites}

Three insect herbivores including a leafminer, $P$. vittatum a weevil, S. ovata, and a thrips, Ctenothrips bridwelli Franklin (Thysanoptera: Thripidae) were found to be associated with the orchids. Two undescribed larval para-

Table 2 Weather Data from Ottawa Airport station.

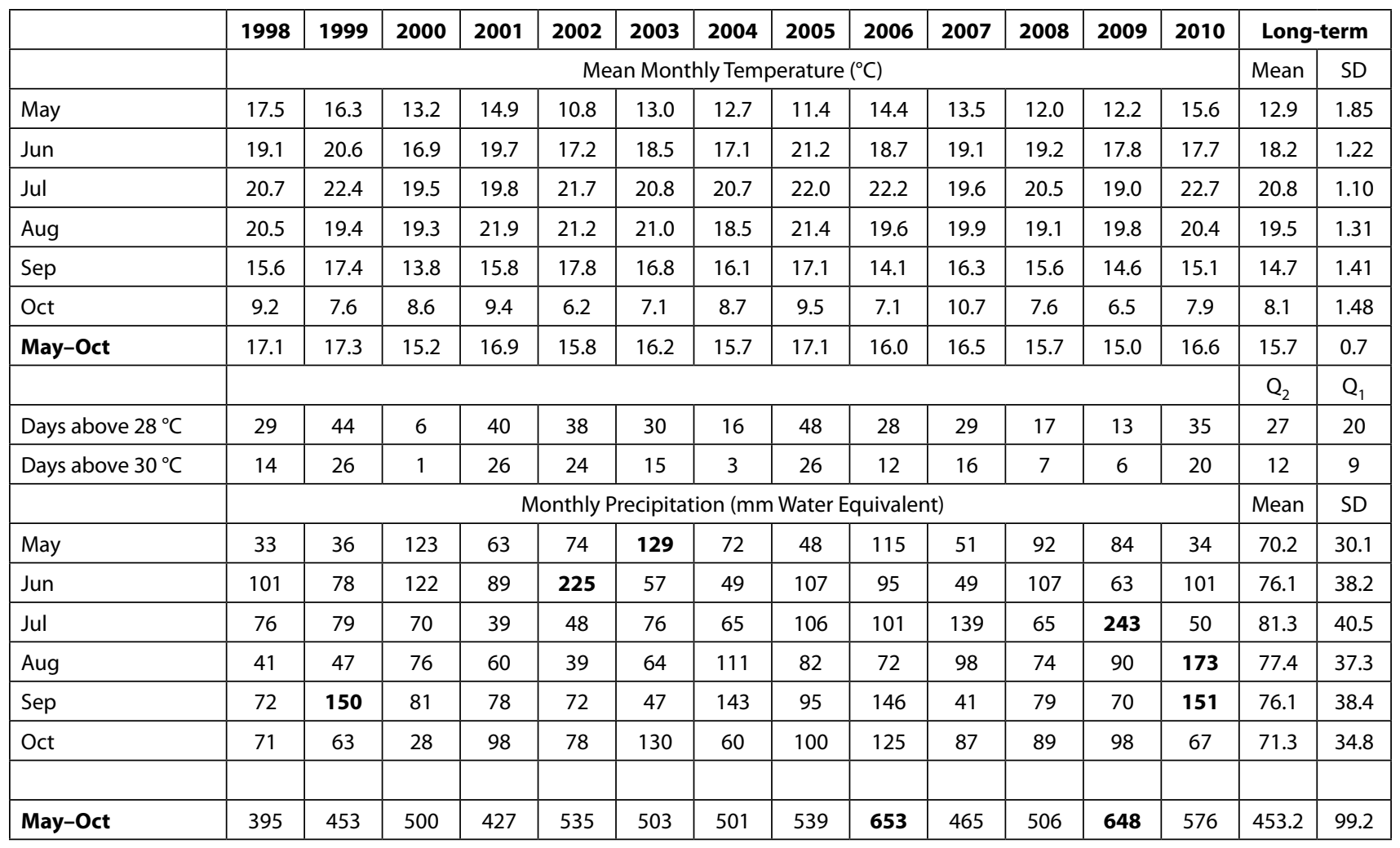

Bold numbers denote values 2 or more standard deviations above the long-term mean. 
sitoids, Utetes spp. Förster (Hymenoptera: Brachonidae), and an egg parasitoid, Chrysocharis sp. Förster (Hymenoptera: Eulophidae) used the leafminer, $P$. vittatum as a host. A predatory thrips was observed feeding on larval thrips and a predatory mite was seen feeding on an adult thrips but these parasites remain to be identified.

\section{Leafminer Parallelomma vittatum}

Parallelomma vittatum (syn. Americina vittata Meigen) was identified by Dr. Richard Vokeroth. This leaf mining fly used all three orchids as hosts: C. parviflorum var. pubescens in 1996 and during 2007-2010, C. reginae from 2005 to 2010, and E. helleborine only in 2009 (Table 3). The earliest and latest observation of leafminer eggs or mines was on 22 May 2007 and on 17 Sept 2009 with C. parviflorum. No leaf mines in C. reginae foliage were observed before late June. Leaf mines in E. helleborine were only found between 14 Aug and 24 Sept, 2009. One herbarium specimen of E. helleborine from Renfrew County, Ontario (1961, TC Brayshaw, CAN 570560) had at least one mine and four eggs on one leaf. No mines were found on 214 herbarium specimens of Cypripedium (parviflorum - 127; reginae - 87) or on any other of the 106 E. helleborine specimens examined.

\section{Weevil Stethobaris ovata}

The weevil, S. ovata, was found to infest both C. parviflorum and E. helleborine but was never found in C. reginae. The infestation reported from 2000 in C. parviflorum (Light and MacConaill 2002) was the second heaviest over the 10 years of observation with $57 \%$ of fruits infested. In 2003, 59\% of fruits were infested but thereafter the infestation level decreased (Table 4). Of the 391 plants monitored in this site, $183(47 \%)$ were never infested, while 126 (32\%) were infested in more than one year, with one plant being infested in 7 of the 10 years (Table 4 ).

Adult weevils were first seen on emerging shoots and flower buds in spring where they caused light feeding damage: adults were occasionally seen in late August before fruits dehisced but these did not appear to be feeding. Epipactis helleborine was a weevil host over the 26-year study but adults were never observed on plants

Table 3 Statistics of infestation of 3 orchid species by Parallelomma vittatum.

\begin{tabular}{|c|c|c|c|c|c|c|c|c|}
\hline Year & 2003 & 2004 & 2005 & 2006 & 2007 & 2008 & 2009 & 2010 \\
\hline \multicolumn{9}{|c|}{ C. parviflorum } \\
\hline Flowering plants seen & 349 & 363 & 377 & 380 & 380 & 383 & 277 & 275 \\
\hline Plants with mines & 0 & 0 & 0 & 0 & 1 & 7 & 4 & 2 \\
\hline Proportion with mines & $0.0 \%$ & $0.0 \%$ & $0.0 \%$ & $0.0 \%$ & $0.3 \%$ & $1.8 \%$ & $1.4 \%$ & $0.7 \%$ \\
\hline \multicolumn{9}{|c|}{ C. reginae } \\
\hline Plants seen & 153 & 58 & 59 & 73 & 260 & 133 & 22 & 55 \\
\hline Plants with mines & 0 & 0 & 3 & 1 & 10 & 9 & 3 & 1 \\
\hline Proportion with mines & $0.0 \%$ & $0.0 \%$ & $5.1 \%$ & $1.4 \%$ & $3.8 \%$ & $6.8 \%$ & $13.6 \%$ & $1.8 \%$ \\
\hline \multicolumn{9}{|c|}{ E. helleborine } \\
\hline Plants with mines & 0 & 0 & 0 & 0 & 0 & 0 & 10 & 0 \\
\hline
\end{tabular}

Table 4 Statistics of weevil (Stethobaris ovata) infestation of Cypripedium parviflorum.

\begin{tabular}{|c|c|c|c|c|c|c|c|c|c|c|c|}
\hline Year & 2000 & 2001 & 2002 & 2003 & 2004 & 2005 & 2006 & 2007 & 2008 & 2009 & Total \\
\hline \multicolumn{12}{|c|}{ Capsules } \\
\hline Observed & 571 & 499 & 408 & 282 & 278 & 249 & 202 & 399 & 268 & 137 & 3293 \\
\hline \multirow[t]{2}{*}{ Infested } & 326 & 127 & 37 & 166 & 85 & 9 & 6 & 23 & 6 & 15 & 800 \\
\hline & $57 \%$ & $25 \%$ & $9 \%$ & $59 \%$ & $31 \%$ & $4 \%$ & $3 \%$ & $6 \%$ & $2 \%$ & $11 \%$ & $24 \%$ \\
\hline \multicolumn{12}{|c|}{ Plants } \\
\hline Observed & 273 & 292 & 333 & 349 & 363 & 377 & 380 & 380 & 383 & 277 & 391 \\
\hline \multirow[t]{2}{*}{ Infested } & 149 & 68 & 27 & 85 & 54 & 8 & 6 & 12 & 2 & 12 & 423 \\
\hline & $55 \%$ & $23 \%$ & $8 \%$ & $24 \%$ & $15 \%$ & $2 \%$ & $2 \%$ & $3 \%$ & $1 \%$ & $4 \%$ & NA \\
\hline \multicolumn{12}{|c|}{ Frequencies of infestation (by plant) } \\
\hline \multicolumn{3}{|c|}{ Number of years with an infestation } & \multicolumn{2}{|c|}{ Never } & 1 & 2 & 3 & 4 & 5 & 6 & 7 \\
\hline \multicolumn{3}{|c|}{ Number of plants } & \multicolumn{2}{|c|}{183} & 82 & 69 & 33 & 18 & 5 & 0 & 1 \\
\hline \multicolumn{3}{|c|}{ Number of capsules infested over study span } & \multicolumn{2}{|c|}{ None } & 1 & 2 & 3 & 4 & 5 & 6 & 7 or more \\
\hline \multicolumn{3}{|c|}{ Number of plants } & \multicolumn{2}{|c|}{183} & 60 & 45 & 25 & 15 & 16 & 15 & 32 \\
\hline
\end{tabular}


before the shoots had fully expanded in late June to early July. Adult weevils fed upon buds, flowers, and oviposited in stems and developing fruits with none of these fruits reaching dehiscence. No evidence of weevil damage was found with herbarium specimens.

\section{Thrips Ctenothrips bridwelli}

Thrips damage was first seen with E. helleborine in 1985 but as those two plants were completely dessicated and no insects were present, only the feeding and faecal droplet pattern suggested the kind of insect was involved. No thrips damage was seen again until 2008 when some adults were located on plants in the vicinity of Site 1 . The thrips was identified by Dr. Robert Foottit, CNC, and confirmed by Dr Lawrence Mound, Commonwealth Scientific and Industrial Research Organisation (Australia), as Ctenothrips bridwelli, which has been reported as an herbivore of various herbaceous plants but not of orchids (Morgan 1913; Chiasson 1986). Subsequently, this thrips was found feeding and breeding at the sites on T. grandiflorum, a wide spread spring-blooming herb which emerged at least four weeks before E. helleborine and some 3 mo before orchid infestation was observed. In 2009, some plants of T. grandiflorum remained green more than 1 mo past typical summer senesence when they continued to be used for feeding, breeding, and resting by adult thrips. Widespread and heavy infestation of E. helleborine was observed in 2009 with many plants becoming completely dessicated by mid August. In 2010, thrips were first seen on T. grandiflorum in mid April and on E. helleborine in early July by which time many orchid plants were infested. During 2010, the orchid was used primarily for adult feeding with few eggs or larvae seen: most of these orchid plants had obvious leaf damage and failed to flower or fruit. Examination of herbarium records revealed several E. helleborine specimens having faecal droplet and feeding damage characteristic of thrips. Notably, feeding evidence was found on the earliest Canadian herbarium specimens of E. helleborine, (1894, HB Cushing, Québec, CAN 16424) and (1890, W and O White, Ontario CAN 16431) as well as on 7 and 13 other specimens from Québec and Ontario respectively.

\section{Cypripedium reginae and the leafminer}

Host selection for oviposition appeared to be random: mines were observed in most areas of the fen, but given the differences in the areas sampled in the different years and the relatively low infestation rates, spatial patterns in the infestations were not detectable. A typical irregularly shaped, communal mine affected about $30 \%$ of a leaf but in most cases only one leaf of the five or six on an adult plant was infested. No leafminers were seen on small seedlings. No mines were observed during 2003 or 2004 when 153 and 58 plants were examined respectively. In 2005 , three vacated mines were found on three plants of the 59 examined. One mine was observed during 2006, 11 mines on 9 plants in 2007, nine mines on 10 plants in 2008, four mines on three plants in 2009, and only one mine during 2010 when 55 plants were surveyed (Table 3). No new mines were found in 2007 after 15 August or in 2008 after 27 July.

Eggs were attached to leaf under surfaces in clutches of 1 to 5 . A total of 28 eggs on 9 plants and 30 eggs on 10 plants were found in 2007 and 2008 respectively. Some one-third of eggs never hatched. In 2007, an egg parasitoid emerged from each of two unhatched eggs two weeks after other puparia from the same leaf eclosed: both were identified by John Huber, CNC, as Chrysocharis sp, possibly beckeri Yoshimoto. Remains of dead larvae were occasionally seen in mines. Of the 13 puparia reared, 9 in 2007 and 4 in 2008 respectively, one yielded a male fly on 8 Aug 2007 after 10 days incubation: this specimen was used for identification and as a voucher for deposit at CNC. The remaining seven larvae reared in 2007 were parasitized by a species of the larval parasitoid Utetes. All but one larval parasitoid eclosed after 9 to 14 days incubation at approximately $20^{\circ} \mathrm{C}$. One puparium which developed on 18 Aug 2007 gave rise to a different Utetes species after diapause $\left(5 \mathrm{mo}\right.$ at $4{ }^{\circ} \mathrm{C}$ followed by 24 days at $20^{\circ} \mathrm{C}$ ). The Utetes specimens were identified to genus by Dr. Robert Wharton (Texas AandM) but remain undescribed as to species.

One plant with a leaf bearing a clutch of five recently hatched eggs found on 2 July 2008 was bagged for in situ rearing. Four of these eggs hatched yielding larvae that pupated. One puparium eclosed a larval parasitoid, Utetes, after 14 days. The 3 remaining puparia never eclosed flies or parasites. Losses from parasitoids and other causes in 2007 and 2008 were above 90\%. Despite extensive and repeated searching during 2003-2007, no eggs or mines were observed on possible alternate hosts sharing the same habitat including C. parviflorum, E. helleborine, Maianthemum racemosum (L.) Link.and Platanthera clavellata (Michx.) Luer, but on 3 July 2008, two plants of $C$. parviflorum growing sympatrically with C. reginae were found with leaf mines where the larvae had already exited.

\section{Cypripedium parviflorum var. pubescens and the leafminer}

Leaf mining activity was first recorded in 1996 but not again until 2007 when a modest leafminer infestation was seen in the principal study area (Tables 3,5 ). Oviposition did not appear to be random with certain plants being repeatedly mined over the 2007-2010 period (Table 5). Given the low overall infestation rates of less than $2 \%$, the probability of the observed reinfestations arising from random oviposition across the whole colony is far less than $10^{-6}$.

During 2009 only, two flies were reared and no parasitoids eclosed. In all other years, reared leafminer larvae were parasitized. 
Table 5 Repeated leafminer infestations in C. parviflorum study site.

\begin{tabular}{|l|c|c|c|c|}
\hline & \multicolumn{4}{|c|}{ Year } \\
\hline Plant ID & $\mathbf{2 0 0 7}$ & $\mathbf{2 0 0 8}$ & $\mathbf{2 0 0 9}$ & $\mathbf{2 0 1 0}$ \\
\hline $1991-147$ & & M & M & M \\
\hline $1991-150$ & M & & M & \\
\hline $1991-182$ & & M & & \\
\hline $1991-274$ & & M & & \\
\hline $2000-030$ & & & & M \\
\hline $2000-080$ & & M & M & \\
\hline $2000-092$ & & & M & \\
\hline $2002-027$ & & M & & \\
\hline Total plants infested & 1 & 5 & 4 & 2 \\
\hline Plants assessed & 380 & 383 & 277 & 275 \\
\hline
\end{tabular}

M: Mine(s) found.

\section{Epipactis helleborine and the leafminer}

The leafminer infested 10 plants in three different locations during 2009 which was the first time in 25 years that P. vittatum had been observed infesting E. helleborine in Gatineau Park. Of 16 larvae reared, six died within the mine, three puparia failed to eclose, five eclosed as adult flies, and four as parasitoids. Two flies, a male and a female, were deposited in LEMQ. On 14 Aug 2009, single mines were found on two E. helleborine in the general vicinity of the $C$. reginae colony: there were puparia within the mines and these already had hatched as flies. Eclosure by the leaf mining fly could be determined by a distal, clean-edged, hinged cap whereas parasitoid emergence was identified by a ragged exit hole in the wall of the puparium.

\section{Discussion}

Orchids are host to specialist and generalist herbivores some of which may be destructive when present in large numbers or when plants are stressed by changes in their environment (Table 1; Swezy 1945; Laštůvka 2009). We have observed in a wetland where C. reginae is in decline that small re-introduced seedlings have become heavily infested with leafminers and that adult plants have been increasingly infested with both leafminers and other insect herbivores (unpublished data). Specialist and generalist parasites of the herbivores can limit their destructive impact but the frequency and extent of both herbivore and parasite presence is stochastic and subject to a complex array of variables (Cobbold et al. 2009; Rull et al. 2009). How weather and climate change might impact such relationships is largely unexplored (Stireman et al. 2005; Battisti 2008; Singer and Parmesan 2010), and how dysfunctional pest-parasite systems might impact orchid populations that have been deliberately established outside their range is unknown. Keel (2007), investigated the mycobiont and photoperiod challenges to the hypo- thetical assisted migration of Habenaria repens Nutt. He concluded that the presence of compatible mycobiont strains in a selected site would be a major component of successful migration.

Parallelomma vittatum is multivoltine with two or three generations per year across all three orchids investigated as potential hosts. According to McAlpine (1987) and Šifner (2008), adults of the Scathophagidae prefer sheltered, humid environments including forests and wetlands: they usually choose monocotyledonous plants over dicotyledonous as hosts. Our observations suggest that exploitation of orchids in Gatineau Park by this leafminer is limited by preferred host assemblage, habitat and orchid phenology. The first host of the leafminer available in any year is $C$. parviflorum var. pubescens which emerges and flowers by mid to late May: expanded foliage suitable for oviposition is typically available by the third week of May. The leafminer presence seemed to be in synchrony with this first host suggesting a common seasonal cue. Both C. reginae and E. helleborine emerged in late May to early June: expanded foliage was available for oviposition by mid to late June.

Leafminer infestation of the introduced E. helleborine in Gatineau Park was a rare event with infestation only seen once, in 2009, and after more than two decades of observation of several thousand plants. Parallelomma vittatum has not to our knowledge been previously reported from E. helleborine in Canada nor were specimens reporting the host as E. helleborine found in either CNC or LEMQ where the adults had been collected from pan/ Malaise traps or reared from larvae on Listera cordata (L.) R. Br. (syn. Neottia cordata (L.) Rich). Only one herbarium specimen with leafminer evidence was found in CAN but lack of infested specimens could arise from the choice of unblemished plants as vouchers. Parallelomma vittatum has been reported as a leafminer of E. helleborine in Europe (Ellis 2007; Pitkin et al. 2011), so its absence in Gatineau Park until 2009 had been puzzling.

In 2009, leafminers were found on E. helleborine especially in humid sites including damp forest and a wooded fen. Weather, especially precipitation and humidity, could have influenced movement of adult flies into orchid communities outside of wetlands as in July 2009 when precipitation was exceptionally high with $243.4 \mathrm{~mm}$ rainfall which was about triple the normal expectation (Table 2). Wet weather and a concomitant absence of parasitoids might have facilitated the outbreak into the E. helleborine population (Umbanhowar and Hastings 2002). Despite repeated observation of several hundred E. helleborine during 2010, no further leafmining activity was seen. It is possible that parasitoid (Utetes) absence in that spring and early summer provided an opportunity for leafminer range expansion but the reappearance of parasitoids in late summer ended the outbreak. This may explain why the miner has not been seen subsequently on E. helleborine but one might also speculate that this orchid is not usually chosen as a host except under specific circum- 
stances which render it attractive for oviposition and herbivory. The presence or absence of entomopathogenic fungal endophytes might be another factor to consider (Vega et al. 2008).

The infestation of C. parviflorum var. pubescens and C. reginae by $P$. vittatum in Gatineau Park was always sparse and sporadic but a few mines could be expected to be found most years during this study. Where the infestation in the $C$. reginae colony appeared to be randomly distributed, this was not the case with C. parviflorum where certain plants were repeatedly infested (Table 5). While the number of mines was always low, we have no explanation why particular plants were singled out for repeated herbivory. These plants all grow in the western part of the colony which is not particularly wet, dry, or differently forested. Furthermore, the infested plants were not isolated individuals but growing closely with other plants which were never infested. We have reported a similar predisposition for certain plants in this colony to be subject to weevil attack but these were not the same plants nor were they located in the same part of the colony (Light and MacConaill 1999). Different patterns of oviposition selection by two different insects is intriguing and warrants further investigation. That we found a fungal endophyte in plants not predated by weevils suggests that biological control mechanisms remain to be elucidated.

Can we reliably predict insect outbreaks that might directly or indirectly impact wild orchids within their current locations or if they were relocated to habitats outside their present range? The chance observation of an apparent asynchrony between a leafminer and its parasitoid and how this outbreak together with high rainfall at a critical time facilitated infestation of the introduced orchid E. helleborine in 2009 underscores how much we have yet to learn about the impact of weather and climate change on orchids and their ecosystem components. The role that weather might play in facilitating herbivory of the introduced E. helleborine by Ctenothrips bridwelli is less clear. Characteristic damage seen with early herbarium specimens, while as yet unconfirmed as being caused by C. bridwelli, suggests that E. helleborine was used as a host soon after its introduction to North America but infestations seem to have always been sporadic. In this study, thrips infestation was spotty to absent in most years until recently when increasing numbers of plants have been infested and heavily damaged. That weather and climate may be drivers of this increase is speculative but Imle (1994) reported regional but temporally separate outbreaks of this thrips in Lilium which suggests weather is a common factor. Our data suggest that some orchids and insects are able to adapt to anomalous weather events to their advantage yet such responses are highly variable depending upon the sensitivity to seasonal cues and possibly to their evolutionary history.

Beetles as a group can be especially damaging to both wild and cultivated orchids and are worldwide (Table 1). Whether in temperate (Champion 1916; Hull Sieg and
O'Brien 1993; Dunford et al. 2006) or tropical/subtropical (Hara and Mau 1986; Gough et al. 1994; Prena 2008) locations, beetles, especially Chrysomelidae and Curculionidae, seem to be a growing challenge to conservation. While doing field work with the yellow lady's-slippers in the 1990's, Charles Sheviak, NY State Museum, observed S. ovata feeding heavily on the perennating buds as they emerged from the soil (Sheviak, pers. comm.). Whether this was an unusual event or was somehow weather related is not known as the sites have not been revisited: the potential for loss of meristematic tissue at the base of ramets of long-lived perennials cannot be taken lightly. Weevils have been increasingly reported as pests of imperiled North American species including Platanthera leucophaea (Nutt.) Lindl. (Dunford, Young and Krauth 2006), and P. praeclara Sheviak and Bowles (Hull Sieg and O'Brien 1993). Adult feeding and oviposition damages flowers, foliage and stems, offering potential entry to bacterial and fungal pathogens. In tropical species, beetles are a frequently encountered herbivore of a wide range of orchids (Hawkeswood 1991a; Gough et al. 1994; Winkler et al. 2005; Rivera-Coto and Corrales-Moreira 2007). Larvae feed within stems and fruits, often completely destroying new shoots, pseudobulbs, and fruits: meristem damage can be the most deleterious (Winkler et al. 2005).

\section{Conclusions}

Our data and the observations of other investigators suggests that both orchids and their associated insect herbivores will face challenges in the future from climate change but that the outcome for any specific assemblage is not at all certain neither is there any means of forecasting behaviour. A paucity of data on the biology and dynamics of multi-tiered relationships (orchid-herbivore-parasite) is the key limiting factor. Furthermore, modelling of climate change is at a macro, population, region or even country level but change happens at the micro, individual plant level. The evolutionary history of each member of an assemblage may be key to predicting specific behaviours in a changing world (Anderson 1993; Becerra and Venable 1999; Dixon 2003; Keel 2007; Cobbold 2009; Chuine 2010). Those studying populations and particularly tracking individuals within populations are encouraged to observe insect herbivory, collect and have insects herbivores identified. Once the components are identified, we may progress further in our understanding.

\section{Acknowledgements}

We thank the National Capital Commission and Gatineau Park for permission to conduct the study; Robert Foottit, Henri Goulet, Anne Howden, John Huber, Eric Maw, Lawrence Mound, Charles Sheviak, Richard 
Vokeroth and Robert Wharton for their assistance with identification of insects, Jennifer Doubt (CAN) for access to the herbarium (CAN), Stéphanie Boucher (LEMQ) and Jeff Cumming (CNC Ottawa) for helpful comments and access to insect collections.

\section{REFERENCES}

Anderson RS (1993) Weevils and plants: Phylogenetic versus ecological mediation of evolution of host plant associations in Curculioninae (Coleoptera: Curculionidae). Mem Entomol Soc Can 165: 197-232.

Bado SG, Sills C, Pannunzio MJ, Zapata R (2002) Aspectos morfológicos, biológicos y daños de Tenthecoris bicolor Scott. 1886 (Heteroptera: Miridae): nuevo agente perjudicial de Amarillidaceae. Bol San Veg Plagas 28: 311-317.

Battisti A (2008) Forests and climate change - lessons from insects. iForest 1: 1-5. http://www.biology-online.org/kb/print .php?aid=4634 Accessed 28 February 2011.

Becerra JX, Venable DL (1999) Macroevolution of insect-plant associations: The relevance of host biogeography to host affiliation. Proc Natl Acad Sci USA 96: 12627-12631.

Berg MP, Kiers ET, Driessen G, van der Heijden M, Kooi BW, Kuenen F, Liefting M, Verhoef HA, Ellers J (2010) Adapt or disperse: understanding species persistence in a changing world. Global Change Biol 16: 587-598.

Brown WJ (1966) Chrysomelidae and Curculionidae: descriptions and notes. Can Entomol 98: 855-859.

Buchanan LL (1935) A new genus and species of Orchid Weevils (Coleoptera, Curculionidae, Barinae). Proc Haw Entomol Soc IX, No. 1: 45-48.

Champion GC (1916) On some weevils attacking orchids. Entomol Mon Mag 52: 200-202.

Chiasson H (1986) A synopsis of the Thysanoptera (thrips) of Canada. Memoir No. 17, Lyman Entomological Museum and Research Laboratory, MacDonald College, McGill University, Ste. Anne de Bellevue, QC.

Chuine I (2010) Why does phenology drive species distribution? Philos Trans R Soc Lond Ser B 365: 3149-3160.

Cobbold CA, Roland J, Lewis MA (2009) The impact of parasitoid emergence time on host-parasitoid population dynamics. Theor Popul Biol 75: 201-215.

Dixon AFG (2003) Climate change and phenological asynchrony. Ecol Entomol 28: 380-381.

Doucette CF (1925) Hymenoptera Eurytomidae Eurytoma orchidearum (Westwood) The Cattleya fly, (Isosoma) Eurytoma orchidacearum Westwood. J Econ Entomol 18: 143-147.

Dunford JC, Young DK, Krauth SJ (2006) Stethobaris ovata (LeConte) (Curculionidae) on Eastern Prairie Fringed Orchid (Platanthera leucophaea (Nutall) Lindley) in Wisconsin. Coleopt Bull 60: 51-52.

Egan JF, Irwin RE (2008) Evaluation of the field impact of an adventitious herbivore on an invasive plant, yellow toadflax, in Colorado, USA. Plant Ecol 199: 99-114.

Ellis WN (2007) Bladmineerders van Europa / Leafminers of Europe. Zoölogisch Museum Amsterdam.

Fiedler K (1992) Notes on the biology of Hypolycaena othona (Lepidoptera, Lycaenidae) in West Malaysia. Nach ent Ver Fr Apollo 13: 107-135.

Funderburk J, Mound L, Sharma J (2007) Thysanoptera inhabiting native terrestrial orchids in northern Florida and southern Georgia. J Entomol Sci 42: 573-581.
Godefroid S, Piazza C, Rossi G, Buord S, Stevens A-D, Aguraiuja R, Cowell C, Weekley CW, Vogg G, Iriondo JM, Johnson I, Dixon B, Gordon D, Magnanon S, Valentin B, Bjureke K, Koopman R (2011) How successful are plant species reintroductions? Biol Conserv 144: 672-682.

Gough N, Bartraeau T, Montgomery BL (1994) Distribution, hosts and pest status of the orchid beetle Stethopachys formosa Baly (Coleoptera: Chrysomelidae). Australian Entomol 21: 49-54.

Gregg KB (2004) Recovery of showy lady's slippers (Cypripedium reginae Walter) from moderate and severe herbivory by whitetailed deer (Odocoileus virginianus Zimmerman). Nat Areas J 24: 232-241.

Hara AH, Mau RFL (1986) The orchid weevil, Orchidophilus aterrimus (Waterhouse): insecticidal control and effect on vanda orchid production. Proc Hawaii Entomol Soc 26: 71-75.

Hawkeswood TJ (1991a) Review of the biology and host plants of the dendrobium beetle Stethopachys formosa Baly (Coleoptera: Chrysomelidae). Victorian Entomol 21: 129-131.

Hawkeswood TJ (1991b) Observations on the biology of Stethopachys papuana Gressitt associated with the orchid Spathoglottis rivularis Schlecht. (Orchidaceae) in Papua New Guinea (Coleoptera, Chrysomelidae, Criocerinae). Spixiana 14: 283-291.

Heinrich C (1926) Revision of the North American moths of the subfamilies Laspeyresiinae and Olethreutinae. US Nat Mus Bull 132: $1-216$.

Hodek I, Honĕk A (2009) Scale insects, mealybugs, whiteflies and psyllids (Hemiptera, Sternorrhyncha) as prey of ladybirds. Biol Control 51: 232-243.

Howden AT (1995) Structures related to oviposition in Curculionoidea. Mem Entomol Soc Wash 14: 53-102. http://www .bladmineerders.nl/index.htm. Accessed 22 May 2011.

Hull Sieg C, O’Brien CW (1993) Stethobaris commixta Blatchley (Coleoptera: Curculionidae) collected from a species of orchid, Platanthera praeclara Sheviak and Bowles, in North Dakota tallgrass prairie. Prairie Nat 25: 91.

Imle EP (1994) Foliage thrips of lilies: a sometimes problem. Q Bull N Am Lily Soc 48: 131.

Jensen DD (1946) The identity and host plants of the blossom midge in Hawaii (Diptera: Cecidomyiidae: Contarinia). Proc Haw Entomol Soc 12: 525-534.

Judd WW (1979) Arthropods associated with the Helleborine orchid, Epipactis helleborine (L.) Crantz, at Dunnville, Ontario. Entomol News 90: 41-44.

Keddy CJ, Keddy PA, Planck RJ (1983) An ecological study of Cypripedium passerinum Rich. (Sparrow's Egg Lady-slipper, Orchidaceae) on the north shore of Lake Superior. Can FieldNat 97: 268-274.

Keel BG (2007) Assisted migration as a conservation strategy for rapid climate change: Investigating extended photoperiod and mycobiont distribution for Habenaria repens Nuttall (Orchidaceae) as a case study. PhD Thesis, Antioch University New England, Keene.

Laštůvka Z (2009) Climate change and its possible influence on the occurrence and importance of insect pests. Plant Protect Sci 45: S53-S62.

Light MHS, MacConaill M (1999) Population ecology of Canadian orchids. In: Clark J, Elliott WM, Tingley G, Biro J (eds) Proceedings of the 16th World Orchid Conference, April 1999, Vancouver Orchid Society, Richmond BC, Canada, pp 229-233.

Light MHS, MacConaill M (2002) Climatic influences on flowering and fruiting of Cypripedium parviflorum var. pubescens. In: Kindlmann P, Willems JH, Whigham DH (eds) Trends and fluctuations and underlying mechanisms in terrestrial orchid 
populations, Backhuys Publishers, Leiden, The Netherlands, pp 85-97.

Light MHS, MacConaill M (2005) Long-term studies: a case for orchid species survival. Selbyana 26: 174-188.

Light MHS, MacConaill M (2006) Appearance and disappearance of a weedy orchid, Epipactis helleborine. Folia Geobot 41: 77-93.

Loomans AJM (2006) Exploration for hymenopterous parasitoids of thrips. B Insectol 59: 69-83.

Martin JH (2005) Aleurodicus talamancenis, a new whitefly species damaging plantation bananas in Costa Rica, with discussion of a montane orchid-feeding population (Sternorrhyncha, Aleyrodidae). Zootaxa 843: 1-10.

McAlpine JF (ed) (1987) Manual of Nearctic Diptera. Monograph No 28. Research Branch, Agriculture Canada, Ottawa.

Morgan AC (1913) New genera and species of Thysanoptera, with notes on distribution and food plants. Proc US Natl Mus 46: 1-55. http://biostor.org/reference/58632. Accessed 14 May 2011.

Mound LA (1976) Thysanoptera of the genus Dichromothrips on Old World Orchidaceae. Biol J Linn Soc 8: 245-265.

Mound LA (2002) Thrips and their host plants: new Australian records (Thysanoptera: Terebrantia). Aust Entomol 29: 49-60.

NatureServe (2008) Comprehensive species report on Cypripedium reginae Walter. http://www.natureserve.org/explorer/servlet $/$ NatureServe? searchName=Cypripedium + reginae $+/$. Viewed 14 May 2011.

Pitkin B, Ellis W, Plant C, Edmunds R (2011) The leaf and stem mines of British flies and other insects. http://www.ukflymines .co.uk/. Viewed 23 May 2011.

Prena J (2008) A synopsis of the orchid weevil genus Orchidophilus Buchanan (Curculionidae, Baridinae), with taxonomic rectifications and description of one new species. Zootaxa 1783: 18-30.

Price PW (1980) Evolutionary biology of parasites. Princeton University Press, Princeton NJ, 237 pp.

Rivera-Coto G, Corrales-Moreira G (2007) Problemas fitosanitarios que amenazan la conservación de las orquídeas en Costa Rica. Lankesteriana 7: 347-352.

Rull J, Wharton R, Feder JL, Guillén L, Sivinski J, Forbes A, Aluja M (2009) Latitudinal variation in parasitoid guild composition and parasitism rates of North American hawthorn infesting Rhagoletis. Environ Entomol 38: 588-599.

Šifner F (2008) A catalogue of the Scathophagidae (Diptera) of the Palaearctic region, with notes on their taxonomy and faunistics. Acta Entomol Mus Nat Pragae 48: 111-196.
Singer MC, Parmesan C (2010) Phenological asynchrony between herbivorous insects and their hosts: signal of climate change or pre-existing adaptive strategy? Philos Trans R Soc Lond Ser B 365: 3161-3176.

Soper JH, Murray L (1985) Helleborine - a 30-year update and analysis of its distribution in Ontario. Mich Bot 24: 83-96.

Sparks TH, Huber K, Dennis RLH (2006) Complex phenological responses to climate warming trends? Lessons from history. Eur J Entomol 103: 379-386.

Squirrell J, Hollingsworth PM, Bateman RM, Dickson JH, Light MHS, MacConaill M, Tebbitt MC (2001) Partitioning and diversity of nuclear and organelle markers in native and introduced populations of Epipactis helleborine (Orchidaceae). Am J Bot 88: 1409-1418.

Stireman III JO et al. (2005) Climate unpredictability and parasitism of caterpillars: Implications of global warming. Proc Natl Acad Sci USA 102: 17384-17387.

Swezey OH (1945) Insects associated with orchids. Proc Hawaii Entomol Soc 12: 343-403.

Szczawnski AF (1959) The orchids of British Columbia. British Columbia Provincial Museum, Handbook No. 16, Victoria, BC.

Umbanhowar J, Hastings A (2002) The impact of resource limitation and the phenology of parasitoid attack on the duration of insect herbivore outbreaks. Theor Popul Biol 62: 259-269.

Vaurie P (1983) A catalog of the Coleoptera of America North of Mexico. Family: Curculionidae, Subfamily Rhynchophorinae. Agriculture Handbook Number 529-143a, Agricultural Research Service, USDA, Washington DC.

Vega FE, Posada F, Aime MC, Pava-Ripoli M, Infante F, Rehner SA (2008) Entomopathogenic fungal endophytes. Biol Control 46: $72-82$.

Vockeroth JR (1987) Scathophagidae. In: McAlpine JF (ed) Manual of Nearctic Diptera, Vol 2, Agriculture Canada, Ottawa.

Winkler IS, Mitter C (2008) The phylogenetic dimension of insect/ plant interactions: a summary of recent evidence. In: Tillmon K (ed) Specialization, Speciation, and Radiation: The Evolutionary Biology of Herbivorous Insects. University of California Press, pp 240-263.

Winkler, M, Hulber, K, Mehltreter, K, Franco, JG, Hietz, P (2005) Herbivory in epiphytic bromeliads, orchids and ferns in a Mexican montane forest. J Trop Ecol 21: 147-154.

Yang LH, Rudolf VHW (2010) Phenology, ontogeny and the effects of climate change on the timing of species interactions. Ecol Lett 13: $1-10$. 